\title{
IAMJ
}

INTERNATIONAL

AYURVEDIC

MEDICAL IOURNAL

Review Article

ISSN: 2320-5091

Impact Factor: 6.719

\section{A REVIEW ON ROLE OF PRAMANAS IN AYURVEDIC RESEARCH METHODOLOGY}

\section{Ankita}

Assistant Professor, Department of Samhita \& Siddhanta, GAMC, Jammu, India

Corresponding Author: ullas.ankita@gmail.com

https://doi.org/10.46607/iamj1609022021

(Published online: February 2021)

Open Access

(C) International Ayurvedic Medical Journal, India 2021

Article Received:17/01/2021 - Peer Reviewed:23/01/2021 - Accepted for Publication:26/01/2021

Check for updates

\begin{abstract}
Research is the process of search for unknown knowledge. Research methodology is the general approach a researcher takes during research process. Research methodology is defined as the specific techniques \& procedures required to identify, select, process and analyze a research problem. Various tools and techniques are required for research. In Ayurveda valid knowledge is termed as Prama and the means or source to acquire knowledge are known as Pramana. These Pramanas are the evidence of the critical scientific approach of Ayurveda. Pramanas are the tools of Research in Ayurveda. Pramanas can be of great importance in developing Ayurvedic Research Methodology. Present paper is aimed to explore the scope \& importance of Pramanas described in Ayurvedic literature in Ayurvedic Research Methodology.
\end{abstract}

Keywords: Pramana, Prarthanumana, Research Methodology, Aptopdesha, Pratyaksha, Anumana, Yukti.

\section{INTRODUCTION}

Development of Science is based on new knowledge, which is a continuous process where the contribution comes from various sources. Ayurveda too has described various sources to acquire knowledge. These sources of knowledge are termed as Pramanas.
Acharya Charaka has used the word Pariksha for Pramana. Pariksha is a tool by which the objects are accurately known. Pariksha means to make confirmatory and complete decision about anything. Establishment of the reality of an object with the help of 
Pramana is Pariksha. According to Acharya Charaka, things are either existent (Sat/Bhava) or non-existent (Asat/Aabhava), \& they can be investigated by four Pramana; viz.

e) Aptopadesha (Authoritative statement)

f) Pratyaksha (Direct Perception).

g) Anumana (Inference)

h) Yukti (Rationale - logical reasoning)

Acharya Charaka has also mentioned that the knowledge of these Pramana i.e. Aptopadesha, Pratyaksha \& Anumana is essential for complete inclusive knowledge of disease. Among all Pramanas; first of all, existing knowledge should be acquired by Aptopadesha \& afterwards examinations to be carried out by Pratyaksha \& Anumana. Aptopadesha is the very first source of information about Ayurveda or any other science. For those who already have basic information about science, the remaining two (Pratyaksha \& Anumana) are stated to be sufficient. Aptopadesha is the sources for the theoretical knowledge in this universe. Thus, Aptopadesha becomes the first means to acquire knowledge. Pratyaksha Pramana corresponds to direct perception of knowledge. Whereas Anumana Pramana pertains to inferential knowledge. YuktiPramana signifies the importance of logical reasoning. With the passage of time research in different branches of Ayurveda is gaining momentum. An ayurvedic researcher has to make a fine balance between modern research tools and basic fundaments of Ayurveda. There exists a dire need to develop an Ayurveda based research methodology with the help of relevant Ayurvedic principles and fundamentals. Pramanas can be of great importance in developing this Ayurvedic Research Methodology.

\section{Materials and Methods}

Present article is a review article. The author has explored and thoroughly studied various Ayurvedic treatise, their commentaries; previous research works and published articles from various research portals to present a comprehensive analysis of scope of Pramana Vigyana in Ayurvedic Research Methodology.

\section{Review on Pramanas}

The word Pramana is derived from ' $M a$ ' dhatu with 'Pra' Upsarga and 'Lyut' Pratyaya. The means for the perception of true knowledge is known as Pramana. As per Chakrapani, Pramana are useful to examine the things for true knowledge. Uplabdhi (availability), Sadhana (source), Gyana (knowledge), Pariksha (Examination) and Pramana are synonyms. Fours Pramanas are accepted in the literature of Ayurveda. These are Aptopdesha, Pratyaksha, Anumana and Yukti Pramanas.

\section{AptopdeshaPramana}

Apta means learned; the precepts of learned that are free from rajas \& tamas are known as 'Aptopadesha' which is taken as a Pramana. Acharya Charaka has described Aptas as persons having pure, obstruction free and doubtless knowledge. They are free from attachment \& aversion. They always speak truth. The words and works of Aptas form Aptopdesha Prama$n a^{l}$.

\section{Pratyaksha Pramana}

A mental faculty instantaneously manifested as a result of the proximity of soul, sense faculties, mind \& the object is known as Pratyaksha ${ }^{2}$. The knowledge which is perceived by sense organs \& mind is called as Pratyaksha \& source of acquiring such knowledge is called as Pratyaksha Pramana. The contact of sense organs \& object is the means of knowledge ${ }^{3}$. Acharya Sushruta has advised coupling of Aptopadesha with Pratyaksha Pramana (direct perception) for advancement of knowledge ${ }^{4}$. Pratyaksha Pramana is of two types: Laukika Pratyaksha (ordinary direct perception) and Alaukika Pratyaksha (extraordinary direct perception). Laukika Pratyaksha is the ordinary perception belonging to the actual world. Whereas Alaukika Pratyaksha is the extraordinary perception based on transcendental contact.

\section{Anumana Pramana}

Inferring knowledge of unknown from the known facts is called as Anumana or Inference. Anumana or inference is the indirect knowledge or logical conclusion based on reasoning. The knowledge perceived after perception of Pratyaksha \& Aptopdesha is called 
Anumana. The cause or source of Anumiti is called Anumana. Anumana Pramana is of two types -

a) Swarthanumana is the cause of assumption of logical inference in one's own mind. Self-inference requires curiosity. Curiosity is the mother of all knowledge. A person with curious \& questioning attitude will search for truth in a scientific manner $\&$ by applying logical process of reasoning he/she will reach to a valid conclusion.

b) Pararthanumana is used to provide knowledge to others. Pararthanumana i.e. Demonstrative inference refers to demonstrating the self-inferred knowledge to others with the help of Panchavayavivakya (5 components of reasoning). Panchavayavi Vakya contains:

a) Pratigya (Proposition), b) Hetu (Reason or Cause),

c) Udaharana (Example), d) Upanaya (Justification),

e) Nigamana (Conclusion)

\section{Yukti Pramana}

The knowledge which sees the things produced by combination of multiple causative factors is Yukti (rationale or logical reasoning). It is true irrespective of times and helps in achieving the three objects (dhar$m a$, artha \& kama). Rational \& fruitful combination of several factors is $Y u k t i^{5}$.

\section{Scope of Aptopdesha Pramana In Research}

\section{Identification of Research Problem}

$>$ Thorough exploration of Aptopdesha is useful in identification of research problem.

$>$ E.g. an analytical study to establish a correlation between manifestations of skin diseases due to Chardivega dharana (suppression of natural urge of vomiting).

\section{Literary \& Historical Review}

$>$ A researcher should survey the relevant literature related to his field of study. Aptopdesha is the source of literary \& historical review in any research.

$>$ Aptopadesha can guide researcher to establish the roots of the study \& reaffirm them with his findings.

\section{Help in Debate, discussion}

$>$ Vadamarga (logical steps required to know before participating in Debates) described in the $8^{\text {th }}$ chap- ter of Charaka Vimana Sthana are meant to make oneself perfect in the art of debate or discussion.

$>$ Vadamarga can guide to improve oratory power needed to educate others by oral means or to communicate with the patients or community regarding healthcare system.

\section{Help in Establishment of Theories}

$>$ Siddhanta, mentioned in 44 Vadamargas are demonstrated truth, established after several examinations \& reasoning 6 . These can be compared to established theories.

$>$ Siddhanta is of four types:

- Sarvatantra Siddhanta (Universal theory)

- Pratitantra Siddhanta (Textual theory)

- Adhikarana Siddhanta (Contextual theory)

- Abhyupagama Siddhanta (Hypothesis)

$>$ Abhyupagama Siddhanta can be considered as a postulate or an assumption taken for granted for the time being. Abhyupagama Siddhanta can be compared with hypothesis which brings clarity, specificity $\&$ focus to a research study.

Example: In an analytical study to establish a correlation between introduction of subject of Research Methodology and Statistics in final year BAMS curriculum with the progress in scientific writing in undergraduate Ayurveda students. Hypothesis can be formulated as:

i) There is no correlation between the introduction of subject of Research Methodology and Statistics in final year BAMS curriculum with the progress in scientific writing in undergraduate Ayurveda students. (As null hypothesis)

ii) The progress in scientific writing in undergraduate Ayurveda students is dependent on the basic knowledge of the subject of Research Methodology and Statistics in final year BAMS curriculum. (As alternative hypothesis)

\section{Scope of Pratyaksha Pramana In Research}

Scope of Pratyaksha Pramana in Research can be understood by following points:

\section{Help in clinical \& Experimental Studies}

$\checkmark$ During clinical \& experimental studies, Pratyaksha Pramana helps in direct perception of Shabda, Sparsha, Rupa \& Gandha except Rasa. 
$\checkmark \quad$ In clinical trials, Pratyaksha Pramana helps in Rogi-Roga Pariksha .

\section{Help in Data Collection}

$\checkmark$ Primary sources of collecting data are observation, interview \& by questionnaire. These methods of data collection depend, more or less on Pratyaksha Pramana.

$\checkmark$ Other methods of data collection are experiments, surveys \& records. Out of these, experiments (in prospective studies) \& to some extent surveys also depend upon Pratyaksha Pramana.

\section{Scope of Anumana Pramana In Research}

Anumana Pramana is utilized during research in a number of ways. Scope of Anumana Pramana in research can be understood by following points:
1) Anumana (Inference) of the cause from the effect - relates to past. This can be correlated with the case control study design (i.e. retrospective study)

2) Anumana (Inference) of the effect from the cause - relates to future. This can be correlated with cohort or prospective study design.

3) Anumana from the commonly observed events at present

This can be correlated with Cross sectional study design (Time prevalence study).

Example: As per quotation from Charak Samhita, Krisha (emaciated) people are more prone to Pliha $\operatorname{rog} a^{8}$. The study to establish correlation between Karshya (emaciation) \& Pliharoga based on Anumana can be designed in following ways:

Table 1: Showing Role of Anumana Pramana in choosing Research Study Design

\begin{tabular}{|c|c|c|}
\hline $\begin{array}{l}\text { uffering presently from } \\
\text { hem about history of } \\
\text { o check whether ema- } \\
\text { aroga or not. }\end{array}$ & risha (emaciated) peo- & $\begin{array}{l}\text { al Study - } \\
\text { valence rate } \\
\text { in krisha } \\
\text { ersons. }\end{array}$ \\
\hline
\end{tabular}

4) Anumana or Inference helps in establishing correlation between two factors.

5) Anumana helps to establish cause-effect relationship between two variables.

6) Anumana Pramana is very important in interpretation of results. Interpretation means drawing inferences from the collected data after an analytical or experimental study.

7) Generalization of results is based on inference only. 8)Help in Writing Research Report/Thesis: Pararthanumana based on Panchavyavi Vakya is an important tool for propagation of knowledge. This can be correlated with research report writing/ thesis writing in the process of research. The aim of research is not fulfilled until the findings are made public via publication of research results.

9) Anumana Pramana helps in examination of patient as described in $4^{\text {th }}$ chapter of Vimana Sthana of Charaka Samhita. E.g. Agni is inferred by digestive power, Bala can be inferred by exercising capacity, strength of sense organs is inferred by reception of sensory knowledge, Medha (intelligence quotient) is inferred by grasping power, Smrit(memory) can be inferred by remembering'.

\section{Scope of Yukti Pramana In Research}

Recognition of Yukti as a means of valid knowledge is the peculiarity of Charak Samhita. Yukti can help and guide a researcher in following ways:

\section{Establishment of Cause- effect relation}

Yukti can be considered as logical reasoning to establish a cause $\&$ effect relationship. In fact, Yukti is rationally based on cause and effect relationship. Although, in Anumana (inference) too; there is causeeffect relationship but only one cause produces the desired effect in Anumana whereas multiple causes can produce effect in case of yukti.

\section{Planning of Research}

Yukti helps in determining various causative factors responsible for any effect. Yukti can also be defined as the rational planning of therapeutic measures. So, the physician/researcher who is efficient in Yukti (logical reasoning) is superior. He can plan his research more 
efficiently. Yukti guides a researcher in research planning in following ways:

$\checkmark \quad$ Yukti helps in deciding dosage, duration \& time of administration of drug.

$\checkmark$ Using instruments \&equipment appropriately requires Yukti.

$\checkmark$ Pathya- apathy kalpna requires application of Yukti.

$\checkmark$ Rogi-roga Pariksha cannot be done by researcher/physician ignoring Yukti.

$\checkmark$ Pharmaceutical preparation of drugs requires Yukti.

\section{DISCUSSION}

Ayurveda is considered one of the most ancient sciences known. Ayurveda greatly relied on the examination tools described as Pramanas. Pramanas are the proof of scientific and evidence-based approach of Ayurveda. Even in modern world any kind of research cannot be accomplished ignoring these four Pramanas. Research pertains to establishing cause and effect relationship in any event. A researcher has to survey the relevant literature related to his field of study. $\mathrm{He}$ must keep himself updated in his field \& related areas. Acharaya Sushruta has stressed on the importance of study of all available texts of any science. He has quoted 'a person who has studied one branch of science only, cannot arrive at proper conclusion; therefore the physician, who has studied all related branches of science, should try to practice the medical science' ${ }^{10}$.Thus, Aptopadesha or authoritative statements help researcher to establish the theoretical roots of the study \& reaffirm them with his findings. Textbooks of great personalities in their respective fields are quoted for authoritative knowledge. One of the qualities of a researcher is that he should acquire existing knowledge \& training in physical \& mental skills necessary to do the activities implied in research. The existing knowledge of science can be acquired through Aptopadesha or authoritative statement. The search for facts is based on two methods: unscientific or arbitrary method and scientific method. Arbitrary method of seeking answers to questions is imaginary or opinion based. From the above discussed refer- ences, it should not be implied that Ayurvedic knowledge is based on arbitrary method. On the contrary, Ayurveda adopts critical scientific method to acquire knowledge. Scientific method is systematic rational approach for seeking facts. It is objective, precise $\&$ arrives at conclusions on the basis of verifiable evidence. The scientific approach of Ayurveda is evident from Pramana Vigyana in ancient Ayurvedic texts. There is huge scope of further exploration of the basic concepts mentioned concisely in Ayurveda. Few such examples are given below:

a. In Charaka Samhita, while explaining Samprapti of Panduroga; it is mentioned that Raktadhatu \& Medodhatu are decreased ${ }^{11}$ but no reasonable explanation about decrease of Medodhatu is given. Therefore, while treating the patients of Pandu Roga more emphasis is given to increase Raktadhatu while Medodhatukshaya is not given due care during course of treatment of Pandu Roga. This topic can be explored for further research.

b. In Ashtanga Hridaya, it is mentioned that Medodhatu Kshaya (decreased Medodhatu) leads to Plihavriddhi ${ }^{12}$ (splenomegaly) but Karya-karana Bhava (cause \& effect relationship) is not explained in the text. This topic provides scope of further research. Similarly, as per Samanya Vishesha Siddhanta, deficiency of Raktadhatu should cause liking for hot items but deficiency of Raktadhatu causes liking for cold items instead of hot items ${ }^{13}$ but proper explanation of this phenomenon is not given in the text.

There are many such examples, where Aptopdesha requires to be explored rationally and logically for the validation of the mentioned phenomena. Thus, study of Ayurvedic texts i.e. authoritative statements are useful in identification of research problem which require further exploration based on scientific methods. There are many relevant topics in which cause, and effect relationship must be explored while researching the Aptopdesha to reaffirm the already stated phenomena in Ayurveda.

Any research may involve two types of approaches. Sometimes, the required information is already available \& needs to be extracted. Whereas sometimes, 
information needs to be collected afresh. Depending upon these two approaches, data can be primary or secondary. Primary sources of collecting data are mainly by observation, interviewing $\&$ by questionnaire. These methods of data collection depend; more or less on Pratyaksha Pramana. Pratyaksha Pramana guides a researcher in taking him close to research hypothesis and investigate research hypothesis. Various experimental studies and clinical trials depend on direct perception by Pratyaksha Pramana for conducting actual research.

Anumana or Inference helps in establishing correlation between two factors or to establish cause-effect relationship between two variables. Anumana helps in attaining knowledge and interpretation of results. Interpretation means drawing inferences from the collected data after an analytical or experimental study. It is search for broader meaning of research findings. Generalization of results is based on inference only. Panchavyavi Vakya can guide a researcher in effective reporting of the research. The framework suggested in Panchavyavi Vakya is found to be very close to the IMRAD format of scientific writing.

Yukti Pramana is an efficient guiding tool for a researcher. Yukti helps in establishing relationship between multiple causes and the effect. It motivates the researcher for better planning of a research study. Planning of research is the key to a fruitful research. Only a well-planned research study can take the researcher close to the results.

The Pramanas guide a researcher in any field of research right from the beginning. All the steps of research starting from choosing the research problem, developing the research hypothesis, collecting the data, interpreting the results, generalization of the results and publication of the research results cannot be executed without four Pramanas. So, while developing an Ayurvedic Research Methodology maximum gravity should be on Pramanas.

\section{CONCLUSION}

Research methodology governs the quality, pattern and direction of research in any field. An Ayurveda based research methodology should be developed with the help of relevant Ayurvedic principles and fundamentals. Aptopdesha, Pratyaksha, Anumanaand Yukti are four Pramans described in Ayurveda. The four Pramans are the guiding light for a research scholar of Ayurveda. Ayurvedic research methodology should be framed based on four Pramanas. An appropriate research methodology in accordance with the basic principles of Ayurveda and Pramanas will surely pave way to path breaking research in Ayurveda.

\section{REFERENCES}

1. Agnivesh, Caraka, Drdhabala - Caraka Samhita, Sanskrit Commentary Ayurveda- Dipika by Chakrapanidutta Edited by Vaidya Jadavaji Trikamji Acharya, Chaukhamba Surabharti Prakshan, Varanasi, Reprint2005. (Charaka Samhita Sutra sthana -11/18,19)

2. Agnivesh, Caraka, Drdhabala - Caraka Samhita, Sanskrit Commentary Ayurveda- Dipika by Chakrapanidutta Edited by Vaidya jadavajiTrikamji Acharya, Chaukhamba Surabharti Prakshan, Varanasi, Reprint2005. (Charaka Samhita Sutra Sthana -11/20)

3. Agnivesh, Caraka, Drdhabala - Caraka Samhita, Sanskrit Commentary Ayurveda- Dipika by Chakrapanidutta Edited by Vaidya Jadavaji Trikamji Acharya, Chaukhamba Surabharti Prakshan, Varanasi, Reprint2005. (Charaka Samhita Vimana Sthana -4/7)

4. Shri Dalhanacarya: 'Nibandhasamgraha' Commentary on Sushruta Samhita, Chowkhamba Sanskrit Series, Varanasi, India; Rep: 2008. (Sushruta Samhita Sharira Sthana 5/48)

5. Agnivesh, Caraka, Drdhabala - Caraka Samhita, Sanskrit Commentary Ayurveda- Dipika by Chakrapanidutta Edited by Vaidya jadavaji Trikamji Acharya, Chaukhamba Surabharti Prakshan, Varanasi, Reprint2005. (Charaka Samhita Sutra sthana -11/25)

6. Agnivesh, Caraka, Drdhabala - Caraka Samhita, Sanskrit Commentary Ayurveda- Dipika by Chakrapanidutta Edited by Vaidya Jadavaji Trikamji Acharya, Chaukhamba Surabharti Prakshan, Varanasi, Reprint2005. (Charaka Samhita Vimana Sthana -8/37)

7. Agnivesh, Caraka, Drdhabala - Caraka Samhita, Sanskrit Commentary Ayurveda- Dipika by Chakrapanidutta Edited by Vaidya jadavaji Trikamji Acharya, Chaukhamba Surabharti Prakshan, Varanasi, Reprint2005. (Charaka Samhita Vimana Sthana -4/7)

8. Agnivesh, Caraka, Drdhabala - Caraka Samhita, Sanskrit Commentary Ayurveda- Dipika by Chakrapa- 
nidutta Edited by Vaidya jadavaji Trikamji Acharya, Chaukhamba Surabharti Prakshan, Varanasi, Reprint2005. (Charaka Samhita Sutra sthana -21/15)

9. Agnivesh, Caraka, Drdhabala - Caraka Samhita, Sanskrit Commentary Ayurveda- Dipika by Chakrapanidutta Edited by Vaidya jadavaji Trikamji Acharya, Chaukhamba Surabharti Prakshan, Varanasi, Reprint2005. (Charaka Samhita Vimana Sthana -4/9)

10. Shri Dalhanacarya: 'Nibandhasamgraha' Commentary on Sushruta Samhita, Chowkhamba Sanskrit Series, Varanasi, India; Rep: 2008. (Sushruta Samhita Sutra Sthana 4/7)

11. Agnivesh, Caraka, Drdhabala - Caraka Samhita, Sanskrit Commentary Ayurveda- Dipika by Chakrapanidutta Edited by Vaidya jadavaji Trikamji Acharya, Chaukhamba Surabharti Prakshan, Varanasi, Reprint2005. (Charaka Samhita Sutra sthana-16/6)

12. Vagbhata - Ashtanga Hrdaya with the commentaries of Sarvangsundara of Arunadatta \& Ayurvedarasayana of Hemadri Edited by Pt. Hari Sadashiva Shastri Paradakara Bhshagacharya, Chaukhamba Surbharati Prakashan, Varansi, India; Reprint -2007. (Ashtanga Hridaya Sutra Sthana 11/18)

13. Vagbhata - Ashtanga Hrdaya with the commentaries of Sarvangsundara of Arunadatta \& Ayurvedarasayana of Hemadri Edited by Pt. Hari Sadashiva Shastri ParadakaraBhshagacharya, ChaukhambaSurbharatiPrakashan, Varansi, India; Reprint -2007. (AshtangaHridaya Sutra Sthana 11/18)

\section{Source of Support: Nil \\ Conflict of Interest: None Declared}

How to cite this URL: Ankita: A Review On Role Of Pramanas In Ayurvedic Research Methodology. International Ayurvedic Medical Journal \{online\} 2021 \{cited February, 2021\} Available from: http://www.iamj.in/posts/images/upload/423_429.pdf 